\title{
The Impact of Principal Leadership and Academic Supervision on Teacher Performance
}

\author{
Nyono $^{1 *}$, Bukman Lian ${ }^{1}$, Mulyadi $^{1}$ \\ ${ }^{1}$ Universitas PGRI, Palembang, Indonesia \\ ${ }^{*}$ Corresponding author. Email: mrnyono017@gmail.com
}

\begin{abstract}
The focus of this research was to identify and evaluate the effect of primary leadership, academic supervision on teacher performance and performance, either partially or simultaneously. The research also examines the impact of principal leadership and academic supervision on the performance of teachers. This type of study is associated with the questionnaire-based data collection tools and the analytical techniques used are validity, reliability, homogeneity, multiple regression analysis, $t$ test and $f$ test. The results showed that the $t$ count value was 9.583>t Table 3.140. Fcount $47.804>$ Ftable 3.15. It means that it can be inferred that there is a simultaneous impact on teacher success between the leadership and academic supervision of the principals $(47,804)$ at a relevant level $(0,000)<0.05$. This study would also illustrate the enhancement of teacher performance through leadership and instructional oversight of principals. The study was conducted at the State Senior High School in the district of Mesuji Raya, with a total of 56 students. And it is concluded that the leadership and instructional supervision of the Principal together contributes $67.6 \%$ to the success of teachers.
\end{abstract}

Keywords: Leadership, Academic Supervision, Teacher Performance

\section{INTRODUCTION}

The achievement of educational objectives in a school depends on the leadership of the school, its educators, its school facilities and its infrastructure. In this journal, the author discusses the impact of leadership and academic supervision in public high schools in the Mesuji Raya district of Ogan Komering Ilir Regency. From the author's point of view, many teachers with S.1 educational qualifications are competently adequate to teach, but in reality, there are still many issues that need to be solved academically. These issues include the large number of teachers arriving late, entering the classroom without any learning resources, the failure to use learning media, and the lack of creativity in teaching. Very few graduation results are accepted at State Universities [1].

The concept of education can be divided into three, i.e. narrow, wide and alternative. The general definition of education is the definition of life in education. Training is all learning experience that takes place in the community and in life (long life education). Education is all life conditions that have an effect on individual development. Simply put, education is characterized as a school, that is to say, a teaching that is carried out or kept in schools as a formal educational institution. The educational process is a public process [2] Education is any impact on children and adolescents that is offered to them in such a way that they have perfect abilities and a complete knowledge of their social connections and duties.

Education is an undertaking that is basic and deliberate, and education is required to create skilled and responsible human beings that are capable of moving into the future. As a leader in his environment, the principal is not only obligated to perform administrative duties, but also concerned with the management of all school programs. He must be able to guide and direct aspects of both administrative and educational processes in his school so that the school he leads becomes complex and dialectical in his innovation efforts. Successful and effective management of the school cannot be isolated from the responsibilities and roles of the principal. School failure and performance are primarily decided by the principal. The Principal must be able to practice creativity, lead all participants and the school as an educational institution to change their minds, develop their vision and purpose by using the strengths, expertise and abilities of its members [3].

The Principal has the authority and policies to enhance the standard of education as a leader [4]. As a 
result, the suspect, as the person who holds the key to enhancing administration and teaching, must be able to perform activities in the sense of creativity, teaching methods, trying out new ideas and trying out new procedures, as well as in the form of more productive classroom management and so on [5].

Giving the right incentive would motivate workers to improve their actions in order to grow and evolve in order to achieve success at work. In order to optimize the achievement of employees' accomplishments, management support is required in its execution, one of which is to provide staff encouragement so that employees can increase their skills according to what management needs, in order to increase their performance according to the objectives of the organization. Teacher motivation must also be wellconditioned so that it can facilitate the smoothness and efficiency of education [6]. Successful teachers can also make significant students [7].

Principal leadership and encouragement have a huge influence on the success of teaching staff. The aim to be accomplished in this context is to improve the output of educators in line with the objectives of the school. Schools that excel are practically inseparable from the success of teachers in these schools. The efficacy of teacher success (performance) can be seen to what degree this performance can affect student behavior [8].

\section{METHODS}

This analysis uses quantitative research methods and the research design is in the form of an influence study, namely to evaluate the impact of the three variables: independent variable or free leadership $\left(\mathrm{X}_{1}\right)$, academic supervision $\left(\mathrm{X}_{2}\right)$ and the dependent or dependent variable Teacher Performance (Y).

The subjects of this study were 65 high school teachers in the Mesuji Raya district, consisting of 30 SMA Negeri 1 Mesuji Raya teachers, 25 SMA Negeri 2 Mesuji Raya teachers and 10 SMA Negeri 3 Mesuji Raya teachers. Collecting data from this analysis using a questionnaire.

The questionnaire used previously was first tested for validation and reliability. It is established from the results of the validation test that the value of $r$ counts all items $>r$ table value, therefore all questions in this study are considered true and accurate. Testing the hypothesis using multiple linear regression, $t$ test and $f$ test in this analysis.

\section{RESULTS AND DISCUSSION}

\section{a. Coefficient of regression (Partial Hypothesis t test)}

The regression coefficient, known as the partial hypothesis test or $\mathrm{t}$ test, measures the effect of each independent variable on the dependent variable or the impact of the leadership variable $\left(\mathrm{X}_{1}\right)$ on the teacher performance variable $(\mathrm{Y})$ and the academic supervision variable $\left(\mathrm{X}_{2}\right)$ on the teacher performance variable $(\mathrm{Y})$ by looking at the $t$ value of the current output. The results of the test can be seen in the table below.

Table 1. T test

\begin{tabular}{|c|c|c|c|c|c|c|}
\hline \multicolumn{7}{|c|}{ Coefficients $^{\mathrm{a}}$} \\
\hline & & \multicolumn{2}{|c|}{$\begin{array}{l}\text { Unstandardized } \\
\text { Coefficients }\end{array}$} & \multirow{2}{*}{$\begin{array}{c}\text { Standardized } \\
\text { Coefficients } \\
\text { Beta } \\
\end{array}$} & \multirow[b]{2}{*}{$\mathrm{t}$} & \multirow[b]{2}{*}{ Sig. } \\
\hline \multicolumn{2}{|c|}{ Model } & $\mathrm{B}$ & Std. Error & & & \\
\hline \multirow[t]{3}{*}{1} & $($ Constant $)$ & -2.264 & 2.523 & & -0.897 & 0.373 \\
\hline & Leadership $\left(X_{1}\right)$ & 0.064 & 0.108 & 0.056 & 0.587 & 0.559 \\
\hline & $\begin{array}{l}\text { Academic } \\
\text { Supervision }\left(\mathrm{X}_{2}\right)\end{array}$ & 1.002 & 0.105 & 0.922 & 9.583 & 0.000 \\
\hline
\end{tabular}

Testing the coefficient of regression of the variable 1. Academic supervision of the principal on the basis of the coefficient table above, the t-count is 0.897 . Hypothesis test: $\mathrm{t}$ count $>\mathrm{t}$ table $=$ accepted $\mathrm{t}$ count .

On the basis of Table 1. The coefficient alluded to above, obtained a $t$ count of 0,582 . Hypothesis testing: $t$ count $>\mathrm{t}$ table $=$ accepted $\mathrm{t}$ count $<\mathrm{t}$ table $=$ denied. Determine $\mathrm{t}$ table $=\mathrm{t}$ table is searched for at 5-007 $=5$ percent: $2=2.5 \%$ (2-sided test) with degrees of freedom (df) $n k-1$ or $65-2-1=62$. ( $\mathrm{n}$ is the number of samples and $\mathrm{k}$ is the number of independent variables). The results of the two-sided test ( significance $=0.025$ ) were obtained for the t table of 1.996. And the following is the test carried out by researchers on the two t-testing variables:

\section{a. Testing the first hypothesis $\left(\mathrm{H}_{1}\right)$}

The meaning of the sig is known. For the effect of $\mathrm{X}_{1}$ on $\mathrm{y}$ is $0.559>0.05$ and the value of $\mathrm{t}$ count is 0.582 $<t$ table 1.996 (count above), so it can be inferred that $\mathrm{H}_{1}$ is rejected, which means that there is no effect of $\mathrm{X}_{1}$ on Y.

\section{b. The Second Hypothesis Test $\left(\mathrm{H}_{2}\right)$}

The meaning of the sig is known. For the effect of $\mathrm{X} 2$ on $\mathrm{y}$ is equal to $0.000<0.05$ and the value of $\mathrm{t}$ count 
9.583> t table 3.140 (count above) so that it can be inferred that $\mathrm{H}_{2}$ is acknowledged, which means that there is an effect of $\mathrm{X}_{2}$ on $\mathrm{Y}$.

\section{c. Multiple statistical analysis of correlation (F Test)}

Multiple statistical correlation analysis was used to assess the relationship between the three existing variables, namely leadership $\left(\mathrm{X}_{1}\right)$, academic supervision
$\left(\mathrm{X}_{2}\right)$ of teacher results $(\mathrm{Y})$. This test is used to determine whether or not the regression coefficient has a major joint effect between the independent variables $\left(\mathrm{X}_{1}\right.$ and $\mathrm{X}_{2}$ ) on the dependent variable (Y). If sog, then. > 5-007 (0.05), the regression coefficient is not important. Multiple correlation analysis is also referred to as the simultaneous hypothesis testing or f-test shown in the table below.

Table 2. Second Hypothesis Test $\left(\mathrm{H}_{2}\right)$

\begin{tabular}{|l|l|r|r|r|r|c|}
\hline \multicolumn{7}{|c|}{ ANOVA $^{\mathrm{a}}$} \\
\hline \multirow{2}{*}{ Model } & Sum of Squares & df & Mean Square & F & Sig. \\
\hline \multirow{2}{*}{1} & Regression & 1488.960 & 2 & 744.480 & 616.881 & $.000^{\mathrm{b}}$ \\
\cline { 2 - 7 } & Residual & 74.824 & 62 & 1.207 & & \\
\cline { 2 - 7 } & Total & 1563.785 & 64 & & & \\
\hline
\end{tabular}

a. Dependent Variable: Teacher Performance (Y)

b. Predictors: (Constant), Academic Supervision $\left(\mathrm{X}_{2}\right)$, Leadership $\left(\mathrm{X}_{1}\right)$.

Based on the above output, it is established that the significance value for the effect of $\mathrm{X}_{1}$ and $\mathrm{X}^{2}$ at the same time on $\mathrm{Y}$ is equal to $0.000<0.05$ and the value of $\mathrm{F}$ count is $616.881>\mathrm{f}$ of table 3.140 so that it can be inferred that $\mathrm{H}^{3}$ is acknowledged, which means that there is an effect of $\mathrm{X}^{1}$ and $\mathrm{X}^{2}$ at the same time on $\mathrm{Y}$.

d. Multiple Correlation Statistical Analysis and Coefficient of Determination

Table 3. Coefficient of Determination

\begin{tabular}{|l|c|r|r|r|}
\hline \multicolumn{5}{|c|}{ Model Summary } \\
\hline & & & & \\
\hline 1 & $.976^{\mathrm{a}}$ & 0.952 & 0.951 & Std. Error of the Estimate \\
\hline \multicolumn{4}{|l|}{ a. Predictors: (Constant), Academic Supervision $\left(\mathrm{X}_{2}\right)$, Leadership $\left(\mathrm{X}_{1}\right)$} \\
\hline
\end{tabular}

$\mathrm{R}=0.976$ means the relationship between the two variables $\mathrm{X}$ (Independent) and the variable $\mathrm{Y}$ (dependent) which implies that the relationship category is strong. $\mathrm{R}^{2}$ of 0.952 means $95.2 \%$ of the $\mathrm{X}$ variable. While the remainder (100-4.8) of $4.8 \%$ can be clarified by other variables not explored in this report.

Standard Error of Estimated (Standard Deviation) implies the calculation of the variance of the expected value. The standard deviation is 1,099 in this case. The lower the standard deviation, the better the model. The data can be seen in the attachment.

The results of a multiple correlation analysis (R) based on the Model Description output obtained a R of 0.952 . Since the multiple correlation value is between $0.80-1,000$, it can be inferred that there is a VERY STRONG connection between leadership and instructional oversight of principals in teacher results. This is in line with the understanding of the coefficient of correlation [9].

\section{e. Determinant Coefficient}

The measurement of the coefficient of determination is used to calculate the percentage of the contribution of the independent variables to the dependent variable. Regression of more than two independent variables used Modified R2 as the decision coefficient. Adjusted R Square is the adjustable $\mathrm{R}$ Square value. The coefficient of determination $\mathrm{R}^{2}$ is 0.952 , which means that the Principal Leadership and Academic Supervision will jointly affect Teacher Output with a contribution of $95.2 \%$, while the remaining $4.8 \%$ is clarified by factorsfactors not included in this analysis.

The Influence of Principal Leadership and Academic Supervision on Teacher Performance

The findings of the study indicate that academic supervision by the principal has a substantial impact on the performance of the teacher. These findings support the hypothesis that academic monitoring by the Principal has a substantial influence on the performance of teachers. Based on the results, it can be explained that if the principal's leadership value $\left(\mathrm{X}_{1}\right)$ increases by 1 
unit score, the teacher's output (Y) will increase by 413 , 1 unit score, given that the academic supervision value of the teacher is constant. As to whether there is a major impact between the Principal's leadership $\left(\mathrm{X}_{1}\right)$ on teacher success $(Y)$. T value of $0.000(p<0.05)$ with a $t$ table of 1.980 or, in other words, $t$ count $>t$ table, so Ho rejects and accepts $\mathrm{Ha}$ or, in other words, this indicates that there is a significant impact between the supervisory variables. Academic performance of the Principal $\left(\mathrm{X}_{1}\right)$ on teacher performance $(\mathrm{Y})$.

The academic leadership and supervision program at SMP Negeri Mesuji Raya is designed to direct teachers to enhance teacher performance through consensus and dialogue with teachers. In formulating priorities, funding for facilities and implementation plans is not sponsored. The application of this leadership and monitoring is accompanied by the initial preparation, the implementation of the observations and the final stage of the learning process, but not all teachers have been supervised in accordance with the programme.

\section{The influence of Academic Supervising on teacher performance}

Based on the findings of the study, it indicates that instructional supervision by the Principal has a substantial influence on the performance of teachers. These findings also support the belief that academic monitoring by the Principal has a substantial influence on the performance of teachers. Regression findings demonstrate that if the value of academic supervision $\left(\mathrm{X}_{2}\right)$ increases by 1 unit score, then teacher output $(\mathrm{Y})$ increases by 0.489 , provided that the principal's leadership value $\left(\mathrm{X}_{1}\right)$ is constant.

As to whether there is a significant impact, the tcount value of the academic supply variable is 3.517 with a significant value of $0.000(\mathrm{p}<0.05)$, so Ho is rejected. This shows that there is a major impact on the output of teachers between academic supervision $\left(\mathrm{X}_{2}\right)$ (Y). This shows that academic supervision $\left(\mathrm{X}_{2}\right)$ influences the success of teachers (Y).

Based on the analysis, it was found that the value of $\mathrm{F}$ count $=68.337$ while the value of $\mathrm{F}$ count $=2.674$ was the value of $\mathrm{F}$ count $>\mathrm{F}$ count with a probability of 0.000 less than 0.05 . This shows that the variable performance of teachers can be explained by differences in academic supervision, school environment and job satisfaction, which are important at the 5\% real level. The multiple linear regression model used is therefore reliable. The coefficient of determination $\left(\mathrm{R}_{2}\right) 0.618$ means that the variables of supervision, school environment and job satisfaction lead $61.8 \%$ to improvements in teacher performance.

\section{The Effect of Leadership and Academic Supervision of Principals Together on Teacher Performance}

Based on the findings of the study, it indicates that leadership and academic oversight of principals on teacher performance together have a substantial influence on teacher performance. These findings support the hypothesis that instructional leadership and oversight of the Principal at the same time have a substantial influence on the performance of teachers. By taking a substantial amount of 0.000 ( $p<0.05$ ), then Ho is denied and $\mathrm{Ha}$ is accepted, this can be seen from the $\mathrm{F}$ test performed where $\mathrm{F}$ count is $47.804>\mathrm{F}$ table is 3.15.

This indicates that it can be inferred that there is a simultaneous impact between leadership and academic supervision of principals on teacher performance and that there is a constructive relationship between leadership and academic supervision of principals on teacher performance. This indicates that the variables of leadership and academic supervision of principals have a common impact on the performance of teachers. Principals need to refine coaching for teachers through the application of instructional supervision and to enhance the transformational leadership implemented in schools in an attempt to increase the performance of teachers so that learning quality can be achieved in the sense of improving the quality of education.

In order to enhance the quality of national education, specific attention needs to be paid to the implementation of classroom learning, since it is where the engagement of information transfer to students takes place, the support of this phase includes the implementation of academic supervision, which can directly influence the teacher, and the support of head transformational leadership. Schools that can empower and encourage teachers to identify and introduce reforms in the learning process so that professional learning can be introduced.

However, the challenges of education are increasingly difficult for teachers to be conscious of on their own. As an imperfect human, the teacher still has a lot of things he does not know and learn. Therefore, the teacher wants the support of those who are close to him to help him, in this case the principal. Teachers are social creatures, such that their competence is affected by the leadership of the principal of the school. Principal management and primary supervision are external influences for teachers. The higher the encouragement given to the teacher and the better the management and supervision of the principal, the greater the impact on the performance of the teacher, since the skill of the teacher and the management and supervision of the headmaster are three separate factors that can balance one another in order to enhance the performance of the teacher. If these three variables can be used together, higher output of the instructor would be achieved. The Principal must be able to practice 
creativity, lead all participants and the school as an educational institution to change their minds, develop their vision and purpose by using the strengths, expertise and abilities of its members [10].

Teacher performance in teaching and learning activities is the aim of teaching materials to be accomplished by any teacher in the school on the basis of the current curriculum. The large number of instructional materials summarized in the curriculum is also not commensurate with the amount of time available on the successful day. On the other hand, all teachers are expected to achieve these objectives. In order to achieve this, a teacher performance strategy needs to be introduced in classrooms. In view of the very important duties and responsibilities of a teacher and a very important aspect in the field of education, a teacher must be able to place his position as a professional staff in line with the demands of an increasingly changing society. As an educator, the teacher is in charge of teaching and instilling values and behaviors in students, in order to carry out this task, the teacher must have different competencies and a groove personality. Teaching is a transfer of knowledge carried out by teachers and students as beneficiaries of that knowledge.

\section{CONCLUSION}

The following can be inferred on the basis of the findings of the data analysis: (1) principal leadership has an impact on the success of students. The magnitude of the impact of leadership on the performance of teachers is $47.3 \%$; (2) the effect of academic supervision on the performance of teachers is $48.9 \%$, the extent of the effect of academic supervision on the performance of teachers is $48.9 \%$, and (3) there is a combined impact of leadership and academic supervision of principals on the success of students, meaning that Ho is rejected and $\mathrm{Ha}$ is approved. Leadership and instructional oversight of principals was able to affect the success of teachers with a contribution of $67.6 \%$, while the remaining $33.4 \%$ were clarified by factors not included in this report.

\section{AUTHORS' CONTRIBUTION}

Nyono: designed and performed experiments and analysed data. Bukman Lian and Mulyadi: Proofing.

\section{ACKNOWLEDGMENTS}

Our deepest gratitude goes to Teachers SMP Negeri Mesuji Raya District, Chancellor of Palembang PGRI University, Director of the Postgraduate Program of PGRI Palembang University and the Education Management Study Program of PGRI Palembang University, who have supported us in doing this extraordinary thing. This project is funded independently. We also want to thank our Education
Management friends who helped us a lot in a short time frame to complete this project.

\section{REFERENCES}

[1] Mudyahardjo, R. (2008). Pengantar Pendidikan Sebuah Studi Awal Tentang Dasar-dasar Pendidikan pada Umumnya dan Pendidikan di Indonesia [Introduction to Education A Preliminary Study of the Basics of Education in General and Education in Indonesia]. Jakarta: Raja Grafindo Persada.

[2] Maseleno, A., Ayshwary, B., Ivanova, T. N., Hashim, W., Nguyen, P. T., Shankar, K., Kristiawan, M., Huda, M. (2019). General Theoretical and Philosophical Aspects of Modern Education. Aspectos Teóricos y Filosóficos Generales de la Educación Moderna. Revista San Gregorio 2019, No. 32 Special Issues August.

[3] Andriani, S., Kesumawati, N., \& Kristiawan, M. (2018). The Influence of the Transformational Leadership and Work Motivation on Teachers Performance. International Journal of Scientific \& Technology Research, 7(7).

[4] Asvio, N., Yamin, M., \& Risnita. (2019). Influence of Leadership Style, Emotional Intelligence and Job Satisfaction toward Organizational Commitment (Survey at SMA Muhammadiyah South Sumatera). International Journal of Scientific \& Technology Research 8 (8).

[5] Arifin, M. (1995). Kapita Selekta Pendidikan (Islam dan Umum), cet.III [Kapita Selekta Pendidikan (Islam and General), cet.III]. Bandung: Bumi Aksara.

[6] Manik, E., \& Bustomi, K. (2011). Pengaruh Kepemimpinan Kepala Sekolah, Budaya Organisasi Dan Motivasi Kerja Terhadap Kinerja Guru Pada Smp Negeri 3 Rancaekek [The Influence of Principal Leadership, Organizational Culture and Work Motivation on Teacher Performance at SMP Negeri 3 Rancaekek]. Jurnal Ekonomi, Bisnis \& Entrepreneurship Vol. 5, No. 2.

[7] Hanim, H., \& Rahmadoni, J. (2020). Determination of Lecturer Reception Using Analytical Hierarchy Process (AHP). Journal of Applied Engineering and Technological Science (JAETS), 1 (2), 136141.

[8] Jurman. (2014). Budaya Organisasi Dalam Meningkatkan Kinerja Guru Pada Sma Negeri 1 Simeulue Timur [Organizational Culture in Improving Teacher Performance at SMA Negeri 1 East Simeulue]. Jurnal Ilmiah DIDAKTIKA.

[9] Sugiyono. (2012). Combination Research Methods (Mixed Methods) [Combination Research Methods (Mixed Methods)]. Bandung: Alfabeta. 